\title{
A STUDY OF WINE FERMENTATION FROM MUCILAGE OF COCOA BEANS (Theobroma cacao L.)
}

\section{Nguyen Thi Thanh Tinha*, Nguyen Tien An ${ }^{a}$, Ho Thi Thu Hoa ${ }^{a}$, Nguyen Thi Tuoi ${ }^{a}$}

${ }^{a}$ The Faculty of Agriculture and Forestry, Dalat University, Lamdong, Vietnam

\section{Article history}

Received: June $04^{\text {th }}, 2016 \mid$ Received in revised form: August $04^{\text {th }}, 2016$

Accepted: August $28^{\text {th }}, 2016$

\begin{abstract}
Cocoa mucilage, a by-product of cocoa beans processing, constitutes $10 \%$ of total cocoa beans, with soluble solids up to $17.78^{\circ} \mathrm{Bx}$, pH of $3.43-3.5$, rich in sugar, minerals, organic acids and phenolic compounds. The aim of this research is to ferment cocoa bean mucilage to produce a beverage with alcohol concentration of $11.2 \%$. The fundamental microorganism for ethanolic fermentation is Saccharomyces cerevisiae with a density of $2 \times 10^{7} \mathrm{cfu} / \mathrm{ml}$ in conjunction with $1 \%(\mathrm{w} / \mathrm{v})$ of commercial fermentation powder product. The product of fermentation was assessed in terms of ethanol concentration, and optimum primary fermentation conditions were at the temperature of $28^{\circ} \mathrm{C}$ with the duration of 7 days. Secondary fermentation, which helped in stabilizing the quality of wine, occurred at $18^{\circ} \mathrm{C}$ for 30 days. The final product attribute is warm orange to bright rust in color, transparent, with a distinct aroma and sensory assessment according to TCVN 3215-79 and 3217 - 79 achieving a good score of 16.39. Therefore, it can be concluded that cocoa bean mucilage can be used for alcoholic beverage fermentation, contributing to diversifying processing products and increasing the application potentials for cocoa.
\end{abstract}

Keywords: Cocoa (Theobroma cacao L.); Mucilage; Wine.

\section{INTRODUCTION}

The sustainable approach for growing of Cocoa trees by mono-cropping or intercropping with cashew trees is widely adopted in Highlands areas. Apart from Daklak, Lamdong is one of the provinces to have a policy aiming at increasing cocoa plantation, specifically in the districts of Dahuoai, Dateh and Cattien. The total plantation for cocoa in the province has reached 1,700 hectares, while in 2008 this number was only 250 hectares. Along with the increase of cocoa plantation and yield, the by-products from cocoa processing are catching a lot of attention from the locals. The extract from cocoa mucilage is one of the by-products with high nutritional value.

\footnotetext{
${ }^{*}$ Corresponding author: Email: tinhntt@ dlu.edu.vn
} 
Therefore, the production of a new product with high economic return from this mucilage will not only solve the pollution problem caused by the by-product but also help in increasing the income for the locals.

Scientists from countries specializing in cocoa tree growing, such as Cote D'Ivoire, Ghana, Indonesia and Brazil mainly focused on research using this by product for the production of fermented or cloudy beverages or jelly. Dias and Schwan (2007) conducted a study on wine production from cocoa mucilage (Theobroma cacao L.). In that research, yeast strains of Saccharomyces cerevisiae (CA116, CA1162 and CA1183) were successfully collected for primary fermentation at $22^{\circ} \mathrm{C}$ and secondary fermentation at $10^{\circ} \mathrm{C}$. Anvoh et al. 2010, researchers from the University of AboboAdjame, Cote D'Ivoire, studied the differences between spontaneous fermentation and the fermentation with Saccharomyces cerevisiae added and controlled.

In Vietnam, studies on cocoa fruits have primarily focused on the seeds, which are the main product. There has been a lack of studies on using cocoa mucilage, a byproduct of cocoa fermentation, for the production of wine. In addition, the fermentation of cocoa mucilage for wine production has been adopted by local people in small scales. Therefore, we decided to investigate the wine fermentation from cocoa mucilage.

\section{MATERIALS AND METHODS}

\subsection{Materials}

Cocoa fruits were cut and the seeds, accounting for $20 \%$ of the fruit weight, were collected. Then, the seed mix were pressed to collect the mucilage which distributes around the seeds. Usually, the mucilage obtained by pressing accounted for around $10 \%$ to $15 \%$ of the total weight. The cocoa mucilage after collection was then frozen to preserve nutritional components. Before the experiment, the frozen mucilage was thawed slowly at room temperature, filtered to eliminate sediments, added with sugar and boiled. Mucilage was purchased from Dahuoai district.

Saccharomyces cerevisiae strains were provided by the Department of Biology, Danang University. Huong Nep wine yeast commercial culture was also used. 


\subsection{Methods}

Viscosity was measured by using Ostwald viscometer (AOAC 974.07). Alcohol content was measured by using Hydrometer REF - 521. Total sugar was determined by the colorimetric method using phenol - concentrated $\mathrm{H}_{2} \mathrm{SO}_{4}$ (Michel et al., 1956). Reducing sugar was determined by the colorimetric method using DNS (Nguyen, 2007). Aldehyde content was determined by a method using iodine TCVN-71. Furfuryl alcohol was determined according to TCVN-71. The number of microbial cells was determined by the colony counting method using PCA (Nguyen \& Bui, 2007). Sensory quality was evaluated according to TCVN 3215-79.

Data collected were analyzed by using Minitab 16 (MiniTab Inc., State College, PA). One-way ANOVA was carried out and the difference between means was assessed at the significant level of 0.05 .

\section{RESULTS AND DISCUSSION}

\subsection{Chemical composition of cocoa mucilage}

Puerari et al. (2012) found that chemical composition of cocoa mucilage consists of $13.1^{\circ} \mathrm{Bx}$ soluble solid, $\mathrm{pH}$ of $3.8,10-15 \%$ of sugar $(60 \%$ sucrose and $39 \%$ glucose and fructose), $2-3 \%$ of pentose. According to Dias and Schwan (2007), soluble solid was $16^{\circ} \mathrm{Bx}$ and $\mathrm{pH}$ was 3.2 .

Table 1 shows that sugar content of cocoa mucilage in this study was lower than that in cited studies while the $\mathrm{pH}$ and soluble solid were relatively similar.

Table 1. Properties of cocoa mucilage $(100 \mathrm{~mL})$

\begin{tabular}{ccccc}
\hline $\mathrm{pH}$ & Brix $\left({ }^{0} \mathrm{~B}\right)$ & Viscosity $(\mathrm{cS})$ & Total sugar $(\mathrm{g})$ & Reducing sugar $(\mathrm{g})$ \\
\hline $3.43-3.5$ & 17.78 & 8.823 & 2.7 & 0.11 \\
\hline
\end{tabular}

\subsection{The ratio of Saccharomyces cerevisiae added}

We used culture medium YPD (Yeast Pepton Dextrose) to breed, preserve and determine the number of Saccharomyces cerevisiae cells. The process was conducted at 
$30^{\circ} \mathrm{C}$ for 48 hours. Czaped-Dox medium was added with $10 \%$ of cocoa mucilage for the proliferation of yeast cells (Nguyen \& Bui, 2007).

After 24 hours of proliferation conducted in shaking machine at ambient temperature, the cell density reached to $2 \times 10^{7} \mathrm{cfu} / \mathrm{mL}$. Cell density was quite stable over times of determination (measuring $\mathrm{OD}_{600}$ ). Therefore, we decided to use the media and condition mentioned above for the following experiments.

To investigate the effect of yeast rates, the experiment was carried out with following treatments: Control, $2.5 \mathrm{~mL}, 5 \mathrm{~mL}, 7.5 \mathrm{~mL}, 10 \mathrm{~mL}$ and $15 \mathrm{~mL}$. The fermentation was at $25^{\circ} \mathrm{C}$ and primary fermentation was 10 days.

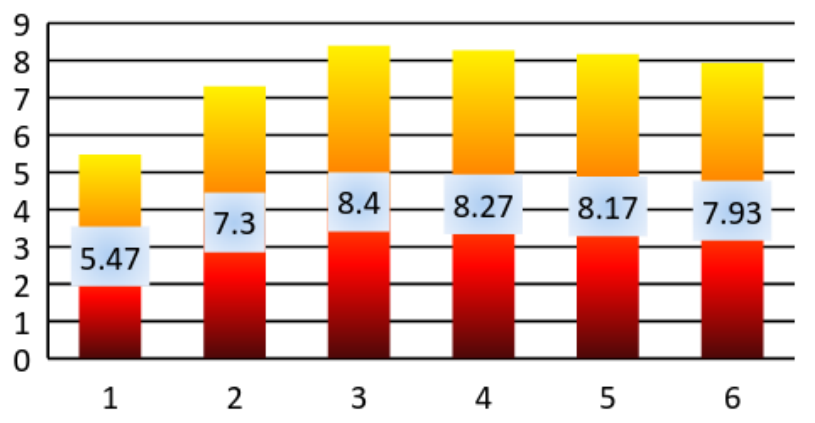

Figure 1. The rate of Sacchromyces cerevisiae affecting fermentation

We used hydrometer REF - 521 to directly measure the alcohol content after fermentation. Based on result showed in Figure 3.1, we found that control samples had the lowest alcohol content, which was 5.47. This is due to spontaneous fermentation. When the rate of yeast added increased (2.5 to $13 \mathrm{~mL})$, the alcohol content increased correspondingly $(7.3-8.4)$ although it leveled off from treatment number 6 where it reached to 7.93. The highest level of alcohol content, which was 8.4, was obtained at treatment 3 where $5 \mathrm{~mL}$ of yeast culture broth was added. Therefore, we chose this rate, which was the addition of $5 \%$ of yeast culture at density of $2.10^{7} \mathrm{cfu} / \mathrm{mL}$, for the following experiments.

\subsection{The ratio of yeast powder addition}

Commercial yeast culture in the forms of yeast powder or "yeast cake" contains microorganisms beneficial for the fermentation of ethanol, mainly consisting of yeast 
and fungi. The fermentation process also created many aroma components which assist in improving the sensory quality of the product. We decided to use both S.cerecisiae yeast culture and yeast powder for the fermentation. The experiment of adding yeast powder was carried out with following treatments: Control, 0.2, 0.4, 0.6, 1 and $1.5 \mathrm{~g}$. The fermentation was conducted at $25^{\circ} \mathrm{C}$ for 10 days.

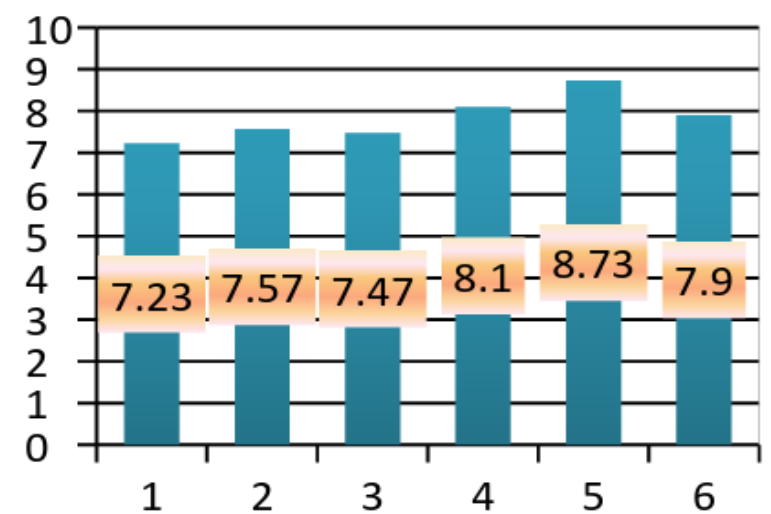

Figure 2. The rate of yeast powder affecting the fermentation

We found that the fermentation products in yeast powder addition treatments had pleasant smell but less pungent and sour than in control. The result showed that the alcohol content was higher when both sources of yeast were added. The alcohol content in treatment 5 was the highest, which was 8.73 , corresponding to the addition of $1 \mathrm{~g}$ of yeast powder.

\subsection{The effect of temperature on fermentation}

\subsubsection{Preparation of mucilage for fermentation}

Cocoa mucilage needed to be added with sugar to obtain soluble solid of $22^{\circ} \mathrm{Bx}$. Several studies used sugar addition of about $10 \%$. The local people in Dahuoai added sugar to $20 \%$. Therefore, we added sucrose at $200 \mathrm{~g} / \mathrm{L}$ of mucilage. The mixture was then pasteurized at $80 \pm 5^{\circ} \mathrm{C}$ in $15 \mathrm{~min}$.

\subsubsection{The effect of temperature on fermentation}

Temperature does not only affect the growth of yeast culture but also affects the rate of alcoholic fermentation and properties and chemical composition of final product. 
According to Dias et al. (2007) the ideal temperature for this process is 5 to $10^{\circ} \mathrm{C}$ higher than optimal temperature, which is in the range of 25 to $30^{\circ} \mathrm{C}$. According to Anvog et al. (2010) and Darman et al. (2011), wine fermentation temperature was usually lower than $25^{\circ} \mathrm{C}$ and fermentation occurs longer than 10 days. Based on published research results on wine fermentation and alcoholic fermentation of cocoa mucilage, we found that the temperature for alcoholic fermentation from cocoa mucilage must be lower than $30^{\circ} \mathrm{C}$. Therefore, we decided to investigate the effect of temperature at the following levels: Control, 22, 24, 26, 28 and $30^{\circ} \mathrm{C}$ in 10 days.

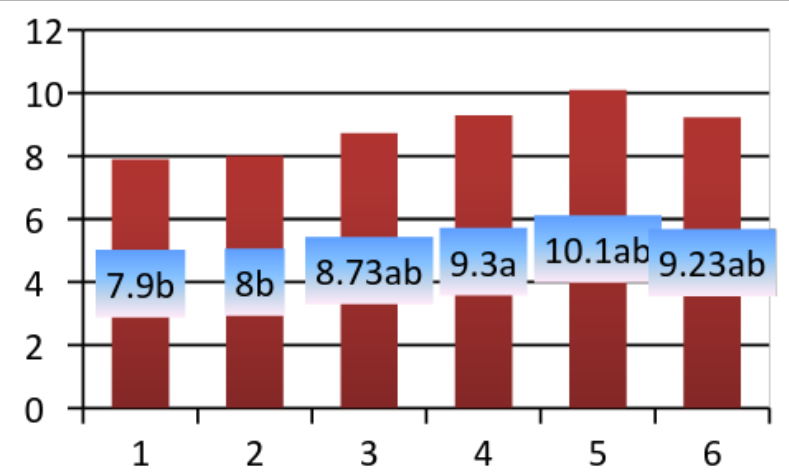

Figure 3. Effect of temperature on fermentation

Note: Means with the same letter are not significantly different at significant level of 0.05 .

As the temperature increases, the fermentation products and secondary products becomes more difficult to be controlled and many toxic products such as acetaldehyde and furfuryl alcohol might be formed. We found that temperature in the range of 26 to $30 \mathrm{oC}$, fermentation occurred intensively and alcohol content reached to 9.23 to 10.1 . The highest level of alcohol was observed in treatment 5 where fermentation temperature was $280 \mathrm{C}$. As temperature increased from 22 to $28^{\circ} \mathrm{C}$, the content of alcohol increased accordingly from 7.9 to 10.1 . However, when temperature increased to $30^{\circ} \mathrm{C}$, the alcohol content of the final product reduced slightly. Therefore, the temperature of $28^{\circ} \mathrm{C}$ was the most suitable for the fermentation with yeast strains that we used for alcoholic fermentation of cocoa mucilage.

\subsection{Effect of fermentation time}

The alcohol content reached 10.9 at treatment 3 (7 days), which was the highest level. When the fermenting time was prolonged to 9 to 13 days, the alcohol content 
tended to reduce gradually to 7.93 (13 days), which was due to the fact that microbes utilized ethanol as a substrate to produce secondary products. There was no statistical difference in the alcohol content between treatment 3 and 4 . Fermentation time in treatment 4 , however, was longer than that in treatment 3. Thus, we decided to choose this treatment, whose primary fermentation time was 7 days.

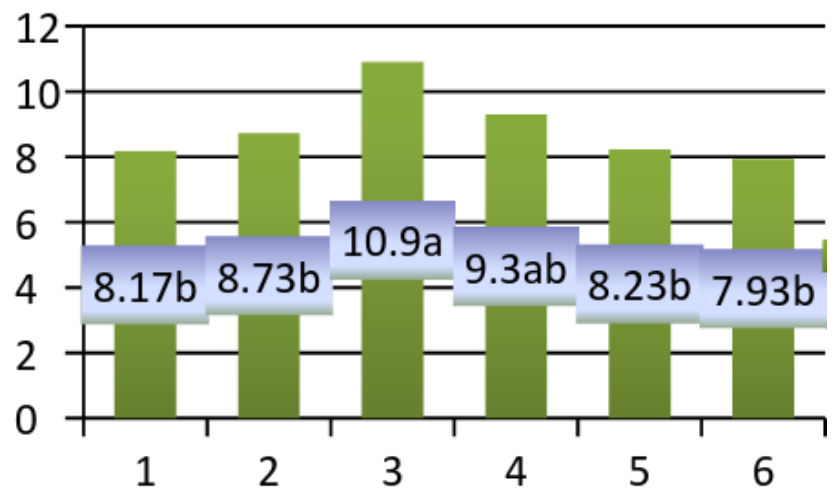

Figure 4. Effect of time on fermentation

Note: Means with the same letter are not significantly different at significant level of 0.05 .

\subsection{Quality assessment of product from alcoholic fermentation of cocoa mucilage}

After the primary fermentation was completed, fermentation vessels were switched to stable fermentation, which occurred at $10^{\circ} \mathrm{C}$ in 10 days. Biochemical occurrence in this period is very complex and critical for the sensory quality of final product.

Table 2. Properties of wine fermented from cocoa mucilage

\begin{tabular}{ccll}
\hline $\mathrm{pH}$ & Alcohol content & Furfuryl alcohol & Aldehyde \\
$4.03-4.26$ & 11.2 & - & - \\
\hline
\end{tabular}

Note: (-) is no indicative color appeared or very light color.

We continued to incubate the fermentation vessels at room temperature $(18-22$ ${ }^{\circ} \mathrm{C}$ ) for 30 days for the secondary fermentation to occur. In Dahuoai District, local people did not handle the two fermentation periods separately. They fermented continuously in 3 months or set a secondary fermentation for 6 weeks. Our final product met the standard requirements for wine stated in TCVN 7045:2002. 
The alcohol content in wines from other studies were $12 \% \mathrm{v} / \mathrm{v}(9.6 \% \mathrm{w} / \mathrm{v})$. According to Dias et al. (2007), a wine product should have an alcohol content of $7.5 \%$ w/v. We measured wine products made from cocoa mucilage in Dahuoai with hydrometer REF - 521 and they reached 10 to $12 \%$. Our product had an alcohol level of 10 to 11.5 . The levels of furfuryl alcohol and aldehyde were in the limit set by TCVN 7045: 2002.

\subsection{Sensory evaluation}

Based on the sensory evaluation table provided in Appendix A, with the total score of 16.39 and based on average scores without important factors for each attributes, along with referring to quality indicators stated in TCVN $3215-79 \& 3217-79$, we found that the wine samples were graded to be good for sensory quality indices. The wine has warm orange to bright rust color, a distinct aroma of cocoa, transparent appearance and no sedimentation.

\section{CONCLUSION}

The raw cocoa mucilage had a distinct aroma, slight viscosity (8.823Cs), soluble solid content of $17.78^{\circ} \mathrm{Bx}$. The total sugar content of the raw material was sufficient and addition of $20 \%$ sucrose was required.

The microbe species for fermentation was Saccharomyces cerevisiae with a density of $2 \times 10^{7} \mathrm{cfu} / \mathrm{ml}$, which accounted for $5 \%$ and the commercial yeast powder addition was of $1 \%$.

The fermentation included two stages. Primary fermentation was at $28^{\circ} \mathrm{C}$ in 7 days and secondary fermentation was at ambient temperature in 30 days.

The wine produced from cocoa mucilage had an alcohol content of 10 to 11.5 and sensory quality was evaluated to be good according to TCVN $3215-79 \& 3217-$ 79. 


\section{REFERENCES}

Anvoh, K.Y.B.M, Gam, B., Kinimo, J. M. \& Gnakri, D. (2010). Comparison of biochemical changes during alcoholic fermentation of cocoa juice conducted by spontaneous and induced processes for the production of ethanol. African Journal of Food Agriculture Nutrition and Development, 10(6), 86-93.

Darman, R. D., Justin, E. \& Xavier, F. E. (2011). Fermentation of cocoa juice (Theobroma cacao L.) and roselle (Hibiscus sabdariffa L.) extracts into a winelike alcoholic drink. Fruit, Vegetable and Cereal Science and Biotechnology, 5(2), 57-63.

Dias, D. R. \& Schwan, R. F. (2007). Elaboration of a fruit wine from cocoa (Theobroma cacao L.) pulp. International Journal of Food Science and Technology, 42, 319329.

Michel, D. \& Gills, K.A. (1956). Colorimetric method for determination of sugars and related substances. Analytical Chemistry, 28, 350-356.

Nguyen, P. T. \& Bui, M. D. (2007). Food Microbiology Episode 2. HaNoi: Medical Publishing House.

Nguyen, V. M. (2007). Biochemistry practice. HaNoi: Vietnam National University Press.

Puerari, C., Karina, T. M. \& Schwan, R. F. (2012). New cocoa pulp-based kefir beverages: Microbiological, chemical composition and sensory analysis. Food Research International, 48, 634-640.

\section{Appendix A: Sensory evaluation results}

\begin{tabular}{|c|c|c|c|c|c|c|c|c|c|c|c|}
\hline \multirow{2}{*}{$\begin{array}{l}\text { Sensory quality } \\
\text { attributes }\end{array}$} & \multicolumn{7}{|c|}{ Member's scores } & \multirow{2}{*}{$\begin{array}{l}\text { Total } \\
\text { score }\end{array}$} & \multirow{2}{*}{$\begin{array}{c}\text { Average } \\
\text { score }\end{array}$} & \multirow{2}{*}{$\begin{array}{l}\text { Important } \\
\text { factor }\end{array}$} & \multirow{2}{*}{$\begin{array}{l}\text { Significant } \\
\text { score }\end{array}$} \\
\hline & AA & $\mathrm{BB}$ & $\mathrm{CC}$ & DD & $\mathrm{EE}$ & $\mathrm{FF}$ & GG & & & & \\
\hline Color, transparency & 4 & 5 & 5 & 3 & 4 & 4 & 4 & 29 & 4.14 & 0.8 & 3.31 \\
\hline Aroma & 4 & 4 & 4 & 4 & 3 & 5 & 4 & 28 & 4.0 & 1.2 & 4.8 \\
\hline Taste & 4 & 4 & 4 & 4 & 4 & 5 & 4 & 29 & 4.14 & 2.0 & 8.28 \\
\hline Total & & & & & & & & & & 4.0 & 16.39 \\
\hline
\end{tabular}




\section{Appendix B: Cocoa wine production flowchart}

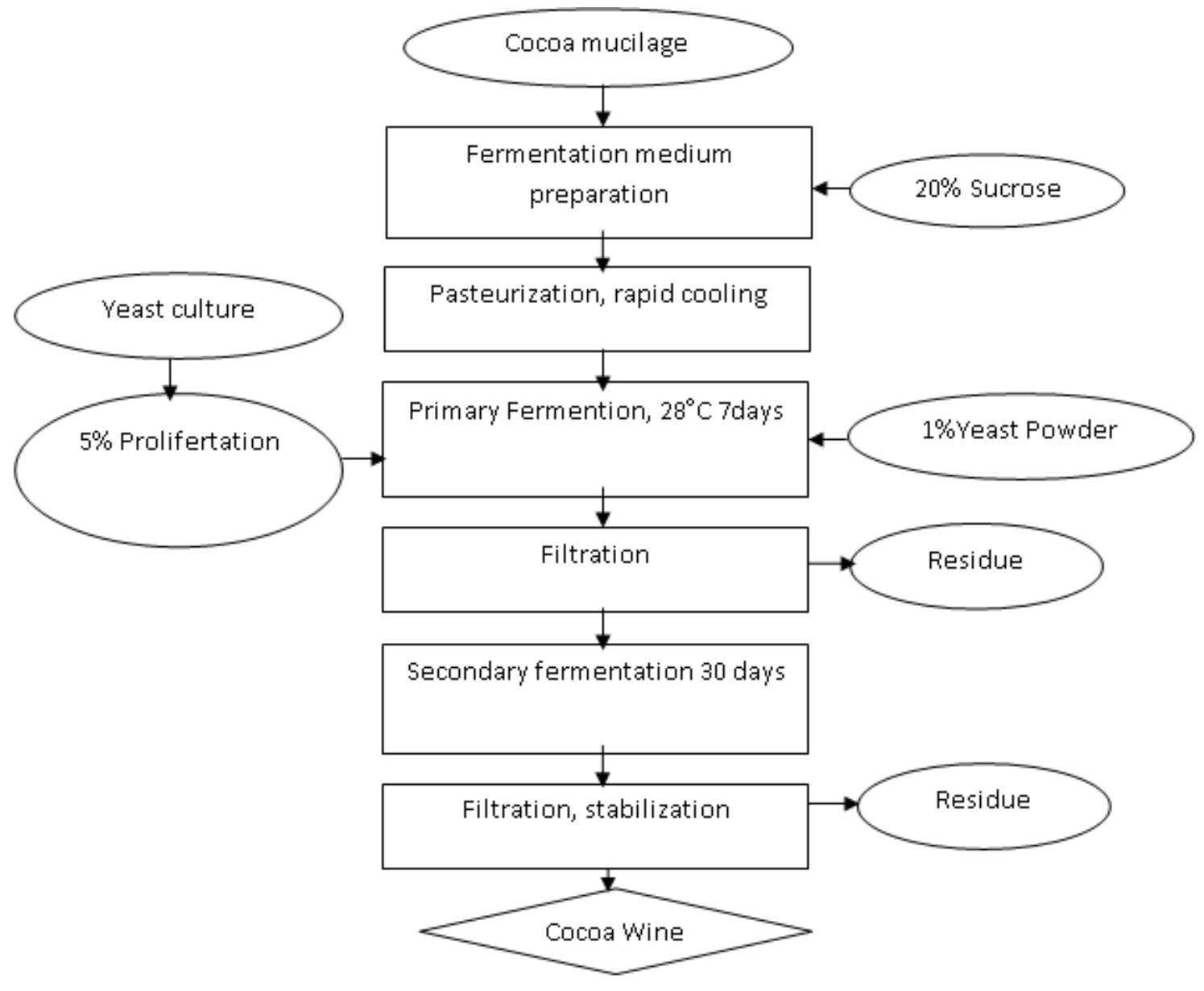




\section{NGHIÊN CÚU QUÁ TRİNH LÊN MEN RƯợU TÙ DỊCH LỚP CƠM NHÂYY HẠT CACAO (Theobroma cacao L.)}

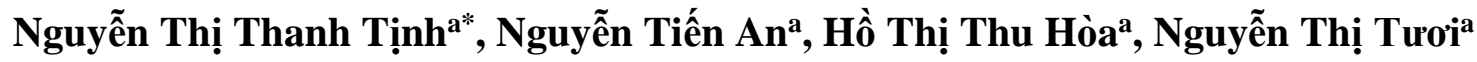

${ }^{a}$ Khoa Nông Lâm,Truò̀ng Đại học Đà Lạt, Lâm Đồng, Việt Nam

*Tác giả liên hệ: Email: tinhntt@dlu.edu.vn

\section{Lịch sử bài báo}

Nhận ngày 04 tháng 06 năm 2016 | Chỉnh sửa ngày 04 tháng 08 năm 2016

Chấp nhận đăng ngày 28 tháng 08 năm 2016

\section{Tóm tắt}

Cơm nhầy hạt cacao chiếm $10 \%$ khối luợng hạt là phu phẩm của quá trình sản xuất hạt cacao, nồng độ chất tan đạt $17.78^{\circ} \mathrm{Bx}$, pH khoảng 3.43 - 3.5 và có giá trị dinh duõng giàu đường, khoáng chất, acid hưu co; phenolic... Nghiên cứu này nhằm muc đích lên men dịch cơm nhầy hạt cacao tạo sản phẩm nước giải khát lên men có độ cồn 11.2. Tác nhân chính của quá trình lên men ethanol là Saccharomyces cerevisiae $2 \times 10^{7} \mathrm{cfu} / \mathrm{ml}$ và phối hợp với $1 \%(w / v)$ chế phẩm bột nem rượu. Quá trình lên men được đánh giá bởi hàm luợng ethanol tạo thành. Điều kiện lên men tối uu ở nhiệt độ $28^{\circ} \mathrm{C}$ và thời gian lên men 7 ngày. Lên men phu ổn định chất lượng ruợu ở điều kiện nhiệt độ trung bình $18^{\circ} \mathrm{C}$ trong vòng 30 ngày. Sản phẩm có màu vàng đển nâu nhạt, trong suốt, mùi thơm đặc trung và đuợc đánh giá cảm quan theo TCVN 3215-79 \& 3217- 79 đạt điểm chung 16.39 mưc khá. Nhu vậy, có thể kết luận rằng có thể chế biến dịch cơm nhầy cacao thành nuoóc giải khát lên men ethanol rươu cacao, đa dạng sản phẩm và tăng thêm khả năng ứng dụng của quả cacao.

Từ khóa: Cacao (Theobroma cacao L.); Lớp cơm nhầy; Rượu. 